\title{
Tumor-to-tumor metastasis: a rare case of breast carcinoma metastasizing to a pheochromocytoma, and a literature review
}

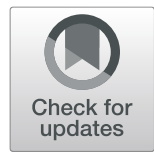

\author{
Weiwei Tan', Lili Tao ${ }^{1 *}$, Zhuping Zhou², Weihua Yin ${ }^{1}$ and Yaoli Chen ${ }^{1}$
}

\begin{abstract}
Background: Tumor-to-tumor metastasis is a well-recognized but uncommon entity. Breast carcinoma is one of the most common metastatic donors. Breast carcinoma metastasizes commonly to adrenal glands. However, the coexistence of a metastatic lesion with an existing adrenal tumor is a rare finding.

Case presentation: A 35-year-old woman was diagnosed with pheochromocytoma using computed tomography and ultrasound examinations. The tumor was surgically removed. Histological and immunohistochemical staining suggested that there were two components in the tumor: pheochromocytoma and metastatic cancer.

Conclusion: This is the second published case of pheochromocytoma with tumor-to-tumor metastasis from an invasive ductal carcinoma of the breast. Furthermore, we highlight the importance of awareness of tumor-to-tumor metastasis in pathological diagnosis.
\end{abstract}

Keywords: Tumor-to-tumor metastasis, Breast carcinoma, Pheochromocytoma

\section{Background}

Tumor-to-tumor metastasis (TTM) is a well recognized but uncommon entity. Lung and breast carcinomas are the most common metastatic donors, while renal cell carcinoma and meningioma are the most common malignant and benign recipients, respectively [1-3]. Breast carcinoma is a malignant lesion and often metastasizes to the adrenal gland [4]. However, metastasis to an adrenal tumor is a rare phenomenon. We present a case of pheochromocytoma with TTM from a breast carcinoma. To our knowledge, this report is the second case of TTM from a breast carcinoma to a pheochromocytoma since Seitz and Schuder reported the first one in 1987 [5].

\footnotetext{
* Correspondence: 651055473@qq.com

1 Department of Pathology, Peking University Shenzhen Hospital, Shenzhen,

Guangdong Province, People's Republic of China

Full list of author information is available at the end of the article
}

\section{Case presentation}

One year ago, a 35-year-old woman underwent computed tomography (CT) scanning following two incidences of paroxysmal hypertension. The scan revealed a tumor above the right kidney. $\mathrm{CT}$ images showed a circular soft tissue density shadow in the right adrenal gland, and the lesion in the arterial phase was markedly heterogeneous with a clear boundary after enhancement (Fig. 1). A needle biopsy was performed and the pathological diagnosis was pheochromocytoma (the report was not available). The patient did not receive treatment at that time. The tumor grew slightly over the subsequent year. Then, the patient came to our hospital for treatment. Ultrasound examination again suggested pheochromocytoma (Fig. 2) and the patient underwent a tumor resection.

(c) The Author(s). 2019 Open Access This article is distributed under the terms of the Creative Commons Attribution 4.0 International License (http://creativecommons.org/licenses/by/4.0/), which permits unrestricted use, distribution, and reproduction in any medium, provided you give appropriate credit to the original author(s) and the source, provide a link to the Creative Commons license, and indicate if changes were made. The Creative Commons Public Domain Dedication waiver (http://creativecommons.org/publicdomain/zero/1.0/) applies to the data made available in this article, unless otherwise stated. 

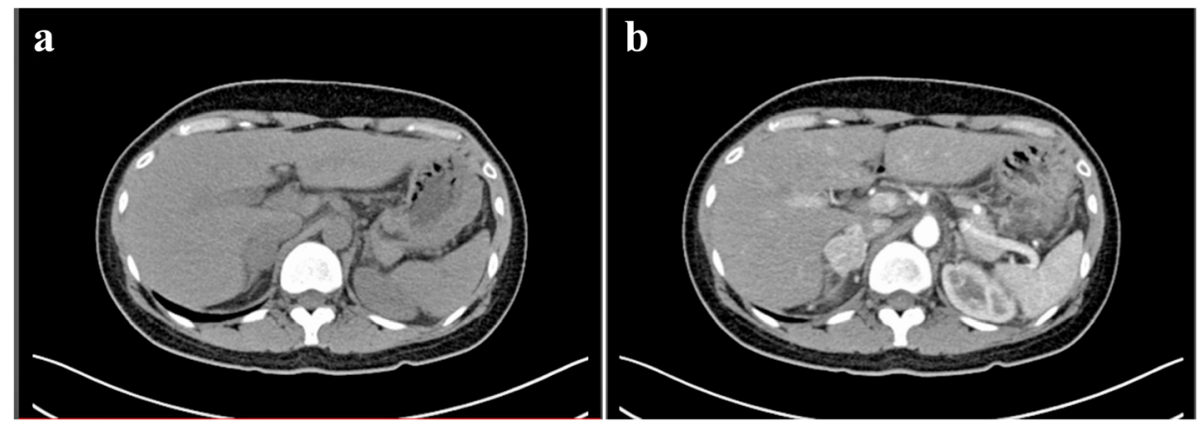

Fig. 1 Computed tomography image showing a circular soft tissue density shadow in the right adrenal gland of the patient (a). The lesion in the arterial phase is markedly heterogeneous with a clear boundary after enhancement (b)

Analysis of the surgical specimen revealed a limited tumor measuring $3.0 \times 2.5 \times 2.3 \mathrm{~cm}^{3}$. The cut surface of the tumor had a half pinkish-grey and half whitish color. The pinkish-grey part was softer than the whitish part.

Histologically, the tumor exhibited a nest-like and trabecular growth pattern. The tumor cells were large, the cytoplasm was eosinophilic, and the nuclei were atypical. Necrosis and mitoses were obviously seen. We initially diagnosed the tumor as a pheochromocytoma. A routine immunohistochemical (IHC) assay was carried out. The results showed that part of the tumor was strongly positive for neuroendocrine markers including chromogranin A (CgA), synaptophysin (SYN) and positive for CD56, but totally negative for cytokeratin (CK). S100 was positive in the sustentacular cells, which supported the diagnosis of pheochromocytoma. Conversely, the other part of the tumor was strongly positive for CK, but negative for CgA, SYN and CD56, as well as S100. In addition, there is a significant difference in the proliferative index (Ki67) between the two parts. (Figs. 3 and 4).
Because of the particular expression pattern seen by IHC in this case, we reviewed the histological sections and found that the tumor consisted of two components. One component exhibited alveolar, trabecular, and diffuse growth patterns. The cells had a polygonal shape and were large with variably sized nuclei, and occasional bizarre giant nuclei. The other part of the tumor showed a nest and sheet growth pattern, and focal necrosis. Cytoplasm of the tumor cells was abundant and eosinophilic, and the nuclei were uniform and regular with prominent nucleoli (Fig. 4). Corresponding to the histology, the cut surface of the tumor exhibited two distinct and well-defined appearances.

Retrospectively, the patient was diagnosed with breast invasive ductal carcinoma 1.5 years ago (without mention of left or right). In addition, left retroperitoneal and thoracic vertebral metastases were confirmed. Hence, we suspected that there may be two components in this tumor: pheochromocytoma and metastatic breast cancer.

In order to verify the composition of metastatic breast cancer, we have added some known breast
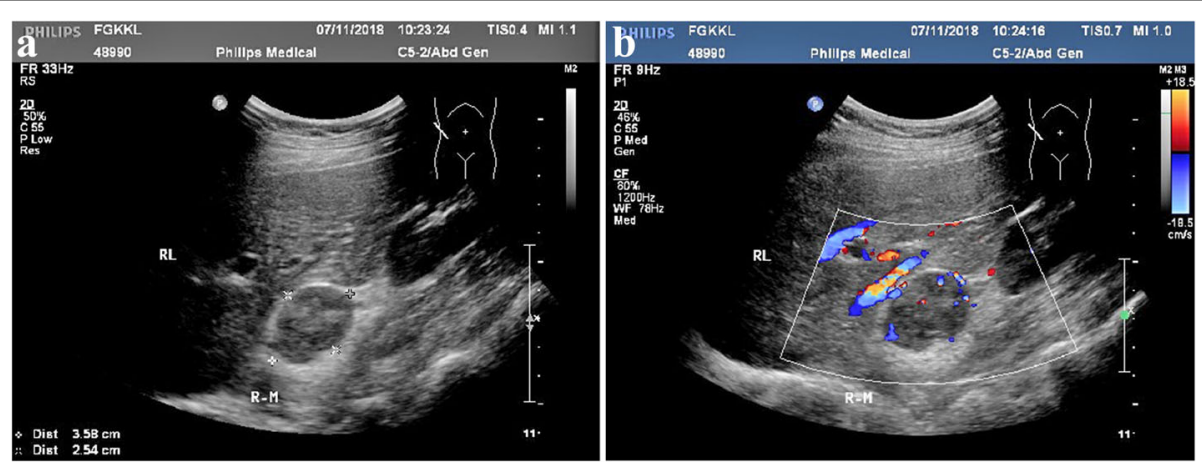

Fig. 2 Ultrasound image showing a hypoechoic mass with a clear boundary in the right adrenal gland. The internal echo is heterogeneous (a). Color Doppler flow image showing a rich blood flow signal inside this mass (b) 

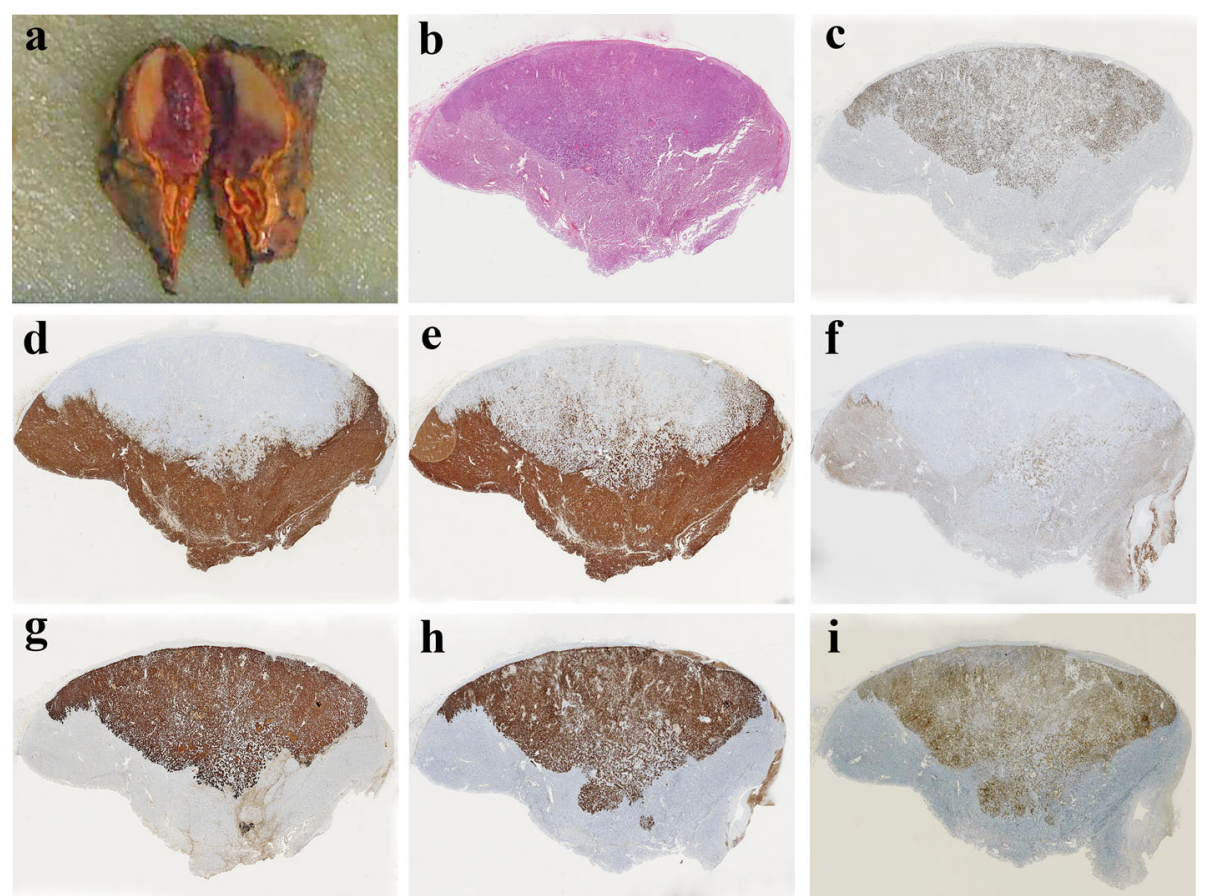

Fig. 3 The cut surface of the tumor is divided into two parts: whitish and pinkish-grey (a). Histological staining with hematoxylin and eosin shows that the cells of both parts are similar (b). The proliferative index (Ki67) of metastatic breast cancer is significantly higher than that of pheochromocytoma (c). Immunohistochemistry shows that pheochromocytoma cells are strongly positive for CgA, SYN and CD56 (d, e and $\mathbf{f}$ ), and metastatic breast carcinoma cells are strongly positive for CK, HER-2 and membrane positive for E-cadherin ( $\mathbf{g}$, $\mathbf{h}$ and i)

markers which include estrogen receptors (ER), progesterone receptors (PR), human epidermal growth factor receptor-2 (HER-2), GATA-binding protein 3 (GATA-3), Mammaglobin A, gross cystic disease fluid protein 15 (GCDFP15) and E-cadherin. The supplementary IHC assay revealed that both tumor cell types were positive for GATA-3 but negative for estrogen and progesterone receptors (ER and PR), despite the slight difference in the intensity of expression of GATA-3 in two tumors. HER-2 was strongly positive (3+), Mammaglobin A and GCDFP15 were weakly positive and E-cadherin was membrane positive in the area where cells were arranged in the nest and sheet pattern with focal necrosis, but completely negative in other areas. Representative images were displayed in Figs. 3 and 4.

\section{Discussion}

TTM is a rare but well-established entity, although the co-existence of two or more primary tumors in an individual is relatively common. After lung, breast cancer is the second most common metastatic donor [2]. According to the literature, breast carcinoma metastases can become invasive ductal [6-10] or lobular carcinomas [11-13]. In addition, a case of mixed carcinoma involving both invasive ductal and invasive lobular carcinomas has been reported [14]. In the last two decades, TTM cases from breast carcinomas have reportedly involved tumors of the central nervous system such as meningioma [3, 15], kidney tumors like renal cell carcinoma $[6,8]$, and tumors of the lung, thyroid, and ovary $[9,11,16-18]$ (Table 1). Among them, metastases to the former two tumor types are more common. According to some researchers, this trend may be related to the rich blood circulation in these areas [5]. The specific mechanism of TTM has not been thoroughly studied. Some experts speculate that hereditary or highly malignant tumors are more prone to TTM [1]. In the present case, the clinical stage of breast carcinoma in the patient was IV, supporting this hypothesis. However, there is no evidence of hereditary tumors.

Cases of breast carcinoma metastasizing to pheochromocytoma, and other malignant tumors to pheochromocytoma, have been reported rarely. The histological appearance of pheochromocytoma is 

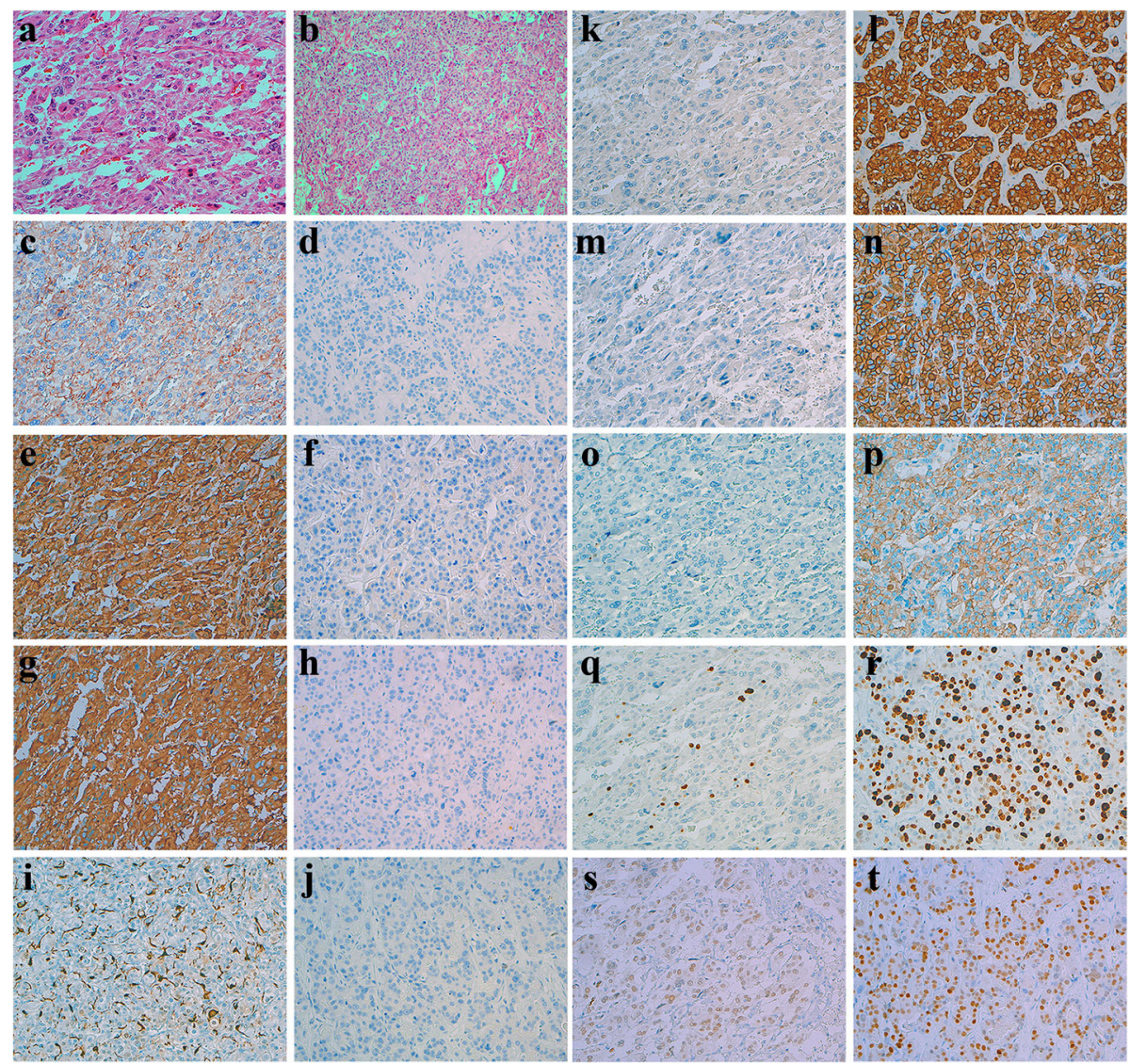

Fig. 4 Comparison of the two tumor components in morphology and IHC staining, $\times 200$. Hematoxylin and eosin staining of two tumor cells (a Pheochromocytoma, b Metastatic breast carcinoma). CD56 is expressed on the membrane of pheochromocytoma cells (c Pheochromocytoma, d Metastatic breast carcinoma). CgA is diffusely expressed in pheochromocytoma (e Pheochromocytoma, $\mathbf{f}$ Metastatic breast carcinoma). SYN is also diffusely expressed in pheochromocytoma cells (g Pheochromocytoma, $\mathbf{h}$ Metastatic breast carcinoma). S100 is expressed in the sustentacular cells of pheochromocytoma (i Pheochromocytoma, $\mathbf{j}$ Metastatic breast carcinoma). CK is stongly positive in metastatic breast cancer cells (k Pheochromocytoma, I Metastatic breast carcinoma). HER-2 is stongly positive (3+) in metastatic breast cancer cells ( $\mathbf{m}$ Pheochromocytoma, $\mathbf{m}$ Metastatic breast carcinoma). E-cadherin is membrane positive in metastatic breast cancer cells (o Pheochromocytoma, $\mathbf{p}$ Metastatic breast carcinoma). The proliferative index (Ki67) of pheochromocytoma is not more than $10 \%(\mathbf{q})$ and that of metastatic breast cancer is about $70 \%(\mathbf{r})$. GATA-3 is weakly positive in pheochromocytoma cells (s) and significantly positive in metastatic breast cancer cells (t)

similar to that of breast invasive ductal carcinoma, which makes the pathological diagnosis more difficult. In the present case, the cells of both tumors were large in size, similarly red-stained, arranged in nest and trabecular shapes, and contained significant atypical nuclei, and many mitotic figures. The diagnosis of pheochromocytoma is normally the first consideration, and a metastatic breast carcinoma is easily missed. In addition, it is worth noting that GATA-3, a protein commonly used to label cells of breast origin, is also expressed in pheochromocytoma cells, which may confuse the diagnosis. Thus, an IHC panel can be helpful to identify pheochromocytoma cells that are positive for CgA, SYN and CD56, but negative for CK. In contrast, cells of metastatic breast carcinoma are positive for CK, but negative for CgA, SYN and CD56. This expression pattern demonstrates the co-existence of an epithelial with a non-epithelial tumor. In addition, epithelial cells are positive for Mammaglobin A, GCDFP15, E-cadherin and strongly positive for HER-2, and supplemental information can reveal that the patient has been clinically confirmed with the occurrence of breast carcinoma metastasis at other sites (peritoneal, thoracic vertebrae, etc.), suggesting that the breast cancer is the source of the metastatic carcinoma.

\section{Conclusion}

This rare case suggests that pathologists should be alert to the presence of TTM when two or 
Table 1 Summary of TTM cases reported in the literature from breast carcinoma

\begin{tabular}{|c|c|c|c|c|}
\hline No. & Type of breast carcinoma & Primary tumor location & $\begin{array}{l}\text { Age, } \\
\text { yrs }\end{array}$ & Reference \\
\hline 1 & Ductal carcinoma & Meningioma & 63 & Pham et al., 2018 [15] \\
\hline 2 & Not mentioned & Meningioma & 50 & Sayegh et al., 2014 [19] \\
\hline 3 & Invasive ductal carcinoma & Meningioma & 72 & Seckin et al., 2006 [20] \\
\hline 4 & Invasive ductal carcinoma & Meningioma & 69 & Okada et al., 2015 [21] \\
\hline 5 & Invasive ductal carcinoma & Meningioma & 63 & Lin et al., 2009 [22] \\
\hline 6 & Invasive ductal carcinoma & Solitary renal angiomyolipoma & 67 & Amin et al., 2013 [10] \\
\hline 7 & Invasive ductal carcinoma & Renal cell cancer & 43 & Huo et al., 2015 [8] \\
\hline 8 & Not mentioned & Benign renal angiomyolipoma & 67 & Diego et al., 2013 [23] \\
\hline 9 & Not mentioned & Renal oncocytoma & 69 & Bitner et al., 2017 [12] \\
\hline 10 & Invasive ductal carcinoma & Solitary fibrous tumor & 64 & $\begin{array}{l}\text { Velez-Cubian et al., } 2016 \\
\text { [9] }\end{array}$ \\
\hline 11 & Invasive ductal carcinoma & Thymic epithelial tumor & 44 & Moretto et al., 2013 [24] \\
\hline 12 & Invasive ductal carcinoma & Vestibular schwannoma & 57 & Lua et al., 2012 [25] \\
\hline 13 & Invasive lobular carcinoma & $\begin{array}{l}\text { Follicular variant of papillary thyroid } \\
\text { carcinoma }\end{array}$ & 50 & Yu et al., 2009 [11] \\
\hline 14 & $\begin{array}{l}70 \% \text { invasive lobular carcinoma and 30\% invasive ductal } \\
\text { carcinoma }\end{array}$ & Recurrent mysoid liposarcoma & 52 & $\begin{array}{l}\text { Kabukcuoglu et al., } 2009 \\
\text { [14] }\end{array}$ \\
\hline 15 & Lobular adenocarcinoma & Granulosa cell tumor of the ovary & 63 & Arnould et al., 2002 [17] \\
\hline 16 & Not mentioned & Benign ovarian fibroma & 68 & Perry et al., 1996 [18] \\
\hline 17 & Lobular breast carcinoma & Superficial plexiform schwannoma & 70 & Gazic et al., 2011 [13] \\
\hline
\end{tabular}

more different histological tumors occur in the same patient or even the same mass. Especially when the morphology of the two tumors is similar, a detailed medical history and IHC assays may play very important roles in the pathological diagnosis.

\section{Abbreviations}

CgA: Chromogranin A; CK: Cytokeratin; CT: Computed tomography; GATA3: GATA-binding protein 3; GCDFP15: Gross cystic disease fluid protein 15; HER-2: Human epidermalgrowth factor receptor-2;

IHC: Immunohistochemical; SYN: Synaptophysin; TTM: Tumor-to-tumor metastasis

\section{Acknowledgements}

Not applicable.

\section{Funding}

This study was supported by a grant from the Science and Research Foundation of Peking University, Shenzhen Hospital (NO. JCYJ201710) and the fund of "San-ming" Project of Medicine in Shenzhen (NO. SZSM201812088).

\section{Availability of data and materials}

All data generated or analysed during this study are included in this published article.

\section{Authors' contributions}

LT and WT participated in the conception of the study and writing of the manuscript. ZZ supplied the CT and enhanced $C T$ image information. WY diagnosed the case. YC produced all histological and immunohistochemical staining slices. All authors have read and approved the final manuscript.
Ethics approval and consent to participate

Ethics was not required for this study as it is a case report of a one-time clinical event.

\section{Consent for publication}

Written informed consent was obtained from the patient for publication of this Case Report and any accompanying images.

\section{Competing interests}

The authors declare that they have no competing interests.

\section{Publisher's Note}

Springer Nature remains neutral with regard to jurisdictional claims in published maps and institutional affiliations.

\section{Author details}

'Department of Pathology, Peking University Shenzhen Hospital, Shenzhen, Guangdong Province, People's Republic of China. ²Department of Imaging, Nanjing Drum Tower Hospital, the Affiliated Hospital of Nanjing University, Nanjing, Jiangsu Province, People's Republic of China.

Received: 24 December 2018 Accepted: 18 April 2019

Published online: 20 May 2019

References

1. Erdogan $\mathrm{H}$, Aydin M, Tasdemiroglu E. Tumor-to-tumor metastasis of the central nervous system. Turk Neurosurg. 2014;24:151-62.

2. Moody P, Murtagh K, Piduru S, Brem S, Murtagh R, Rojiani A. Tumor-totumor metastasis: pathology and neuroimaging considerations. Int J Clin Exp Pathol. 2012;5:367-73.

3. Sayegh E, Burch E, Henderson G, Oh T, Bloch O, Parsa A. Tumor-to-tumor metastasis: breast carcinoma to meningioma. J Clin Neurosci. 2015;22:268-74.

4. Wagnerova H, Lazurova I, Felsoci M. Adrenal metastases. Bratisl Lek Listy. 2013;114:237-40.

5. Seitz G, Schüder G. Neoplasm to neoplasm metastasis. Pheochromocytoma harboring a metastasis of breast cancer. Pathol Res Pract. 1987;182:228-32. 
6. Urdiales-Viedma M, Luque R, Valle F, Martos-Padilla S. Clear cell renal cell carcinoma metastasized by a breast ductal carcinoma. Arch Esp Urol. 2016; 69:197-201.

7. Tally P, Laws E, Scheithauer B. Metastases of central nervous system neoplasms. Case report. J Neurosurg. 1988;68:811-6.

8. Huo Z, Gao Y, Yu Z, Zuo W, Zhang Y. Metastasis of breast cancer to renal cancer: report of a rare case. Int I Clin Exp Pathol. 2015;8:15417-21.

9. Velez-Cubian F, Gabordi R, Smith P, Toloza E. Tumor-to-tumor metastasis: an unusual case of breast cancer metastatic to a solitary fibrous tumor. J Thorac Dis. 2016;8:E374-8.

10. Amin M, Radkay L, Pantanowitz L, Fine J, Parwani A. Tumor-to-tumor metastasis (TTM) of breast carcinoma within a solitary renal angiomyolipoma: a case report. Pathol Res Pract. 2013;209:605-8.

11. Yu J, Nikiforova M, Hodak S, Yim J, Cai G, Walls A, Nikiforov Y, Seethala R. Tumor-to-tumor metastases to follicular variant of papillary thyroid carcinoma: histologic, immunohistochemical, and molecular studies of two unusual cases. Endocr Pathol. 2009;20:235-42.

12. Bitner D, Clements M, Cathro H, Mithqal A, Schenkman N. Remote development of tumor-to-tumor metastasis of breast adenocarcinoma in a renal Oncocytoma. Urology. 2017;107:e1-2.

13. Gazic B, Pizem J. Lobular breast carcinoma metastasis to a superficial plexiform schwannoma as the first evidence of an occult breast cancer. Am J Dermatopathol. 2011;33:845-9.

14. Kabukcuoglu F, Kabukcuoglu Y, Tanik C, Sakiz D, Karsidag S. Breas carcinoma metastasis in recurrent myxoid liposarcoma. Pathol Oncol Res. 2009;15:467-71.

15. Pham J, Kim R, Nguyen A, Bota D, Kong X, Vadera S, Hsu F, Carrillo J. Intracranial meningioma with carcinoma tumor-to-tumor metastasis: two case reports. CNS Oncol. 2018;7:CNS09.

16. Ro J, Guerrieri C, el-Naggar A, Ordóñez N, Sorge J, Ayala A. Carcinomas metastatic to follicular adenomas of the thyroid gland. Report of two cases. Arch Pathol Lab Med. 1994;118:551-6.

17. Arnould L, Franco N, Soubeyrand M, Mege F, Belichard C, Lizard-Nacol S, Collin F. Breast carcinoma metastasis within granulosa cell tumor of the ovary: morphologic, immunohistologic, and molecular analyses of the two different tumor cell populations. Hum Pathol. 2002;33:445-8.

18. Perry L, Lewis J, Ball R. Adenocarcinoma of the breast metastatic to benign ovarian fibroma. Gynecol Oncol. 1996;62:408-10.

19. Sayegh E, Henderson G, Burch E, Reis G, Cha S, Oh T, Bloch O, Parsa A. Intrameningioma metastasis of breast carcinoma. Rare Tumors. 2014;6:5313.

20. Seckin H, Yigitkanli K, Ilhan O, Han U, Bavbek M. Breast carcinoma metastasis and meningioma. A case report. Surg Neurol. 2006;66:324-7 discussion 27.

21. Okada E, Nakamura M, Koshida Y, Mukai K, Toyama Y, Matsumoto M. Breast carcinoma metastasis to meningioma in the thoracic spine: a case report and review of the literature. J Spinal Cord Med. 2015;38:231-5.

22. Lin J, Su F, Wang H, Lee T, Ho J, Lin C, Lin Y. Breast carcinoma metastasis to intracranial meningioma. J Clin Neurosci. 2009;16:1636-9.

23. Diego E, McGuire K. A rare case of tumor-to-tumor metastasis: breast cance metastatic to a benign renal mass. J Surg Case Rep. 2013;2:

24. Moretto R, Cella C, Raimondo L, Formisano L, Nappi L, Rescigno P, Buonerba C, Calabrese F, Ottaviano M, Di Lorenzo G, Matano E, Damiano V, Palmieri G. Tumor-to-tumor metastasis: breast cancer metastatic to thymic epithelial tumor. Anti-Cancer Drugs. 2013;24:759-64.

25. Lua B, Lieu A, Hwang S. Breast carcinoma metastasized to vestibular schwannoma: a rare case of tumor-to-tumor metastasis and literature review. Kaohsiung J Med Sci. 2012;28:397-9.

Ready to submit your research? Choose BMC and benefit from:

- fast, convenient online submission

- thorough peer review by experienced researchers in your field

- rapid publication on acceptance

- support for research data, including large and complex data types

- gold Open Access which fosters wider collaboration and increased citations

- maximum visibility for your research: over $100 \mathrm{M}$ website views per year

At $\mathrm{BMC}$, research is always in progress.

Learn more biomedcentral.com/submissions 